\title{
Mardin şehrindeki taştan yapılmış eserlerde görülen bozunmalar
}

\author{
Murat DAL ${ }^{1, *}$, Ali Duran ÖCAL ${ }^{2}$ \\ ${ }^{1}$ Munzur Üniversitesi Mühendislik Fakültesi İnşaat Mühendisliği Bölümü, Aktuluk kampüsü, Tunceli. \\ ${ }^{2}$ Universidad Nacional de Colombia, Fakultad de Ciencias Humanas,Departamento de Antropologia, \\ Bogota, Kolombiya.
}

Geliş Tarihi (Recived Date): 13.01.2017

Kabul Tarihi (Accepted Date): 08.03.2017

\section{Özet}

Tarih boyunca insanlar tarafindan yapllarak kullanılagelmiş tüm yapılar, doğa ve yine insan kaynaklı bir bozunma süreciyle karşı karşıya kalmaktadırlar. Bu sürecin sonucu olarak ta tarihsel değerdeki birçok yapı, geri dönülmesi çok zor olan bozunma süreci nedeniyle bir kültürel-değer kaybına uğramaktadır. Mardin, tarihsel doku olarak ülkemizin en önemli şehirlerinden biri olarak, içerdiği yapıların da aynı akıbete uğrama olasılığının yüksek olmasından dolayı, araştırma konusu olarak seçilerek kentteki tarihi taş yapılarındaki bozunmalar incelenmiştir. Bu çalışmanın amacı, tarihsel değerdeki yapıların yıpranmasına dikkat çekilerek korunma önlemlerinin zaman kaybetmeden başlanmasını sağlamaktır. Araştırma sonucunda Mardin kentindeki tarihi taş eserlerde genel olarak mekanik bozulmaların yanında biyolojik bozunmalar ve hatalı restorasyon uygulamalarının yoğunlaştığı gözlenmiştir.

Anahtar kelimeler: Mardin, doğal yapı taşı, tarihsel yapı, bozunma, tahribat.

\section{Decay of stone elements in Mardin City buildings}

\begin{abstract}
All structures which were constructed and used by humans throughout the history were faced with a decay proccess caused by the nature and humans. As a consequence of this process, which is also very difficult to return, many historical structures undergoing a cultural depreciation due to the process of disintegration. Since Mardin is one of the most important cities of our country as a historical texture and the likelihood of the structures, it has been selected as a research theme and the degradation of historical buildings in the city has been examined. The purpose of this study is to draw
\end{abstract}

\footnotetext{
*Murat DAL, teknikmurathoca@gmail.com, http://orcid.org/0000-0001-5330-1868

Ali Duran ÖCAL, adocal@unal.edu.co, http://orcid.org/0000-0003-2283-640X
} 
attention to the degradation of the historical structures and to ensure that preventive measures are started without delay. As a result of the research, it has been observed that in the historical stone works in Mardin city, in addition to mechanical deterioration in general, biodegradation and erroneous restoration applications have been intensified.In this study.

Keywords: Mardin, natural construction stone, historical building, weathering, decay.

\section{Giriş}

Mardin ili, tarih öncesi dönemlerde önemli bir ticaret yollarından biri olması nedeniyle (İpek Yolu) yoğun iskânlar görerek kültürlerarası ilişkilerin oluşmasında önemli bir rol oynamıştır. Bu özelliğinden dolayı, farklı dini inanışlar paralelinde, kültürel ve sanatsal açıdan tarihsel değeri olan ve uluslararası kuruluşlarca kültür mirası kabul edilmiş çok sayıda kilise, manastır, cami, türbe, çeşme, hamam ve benzeri yapıları bünyesinde bulundurmaktadır. Nitekim bölgede Kültür ve Tabiat Varlıkları Koruma Bölge Müdürlügünce tescil edilmiş 600 den fazla bina mevcuttur (Şekil 1).

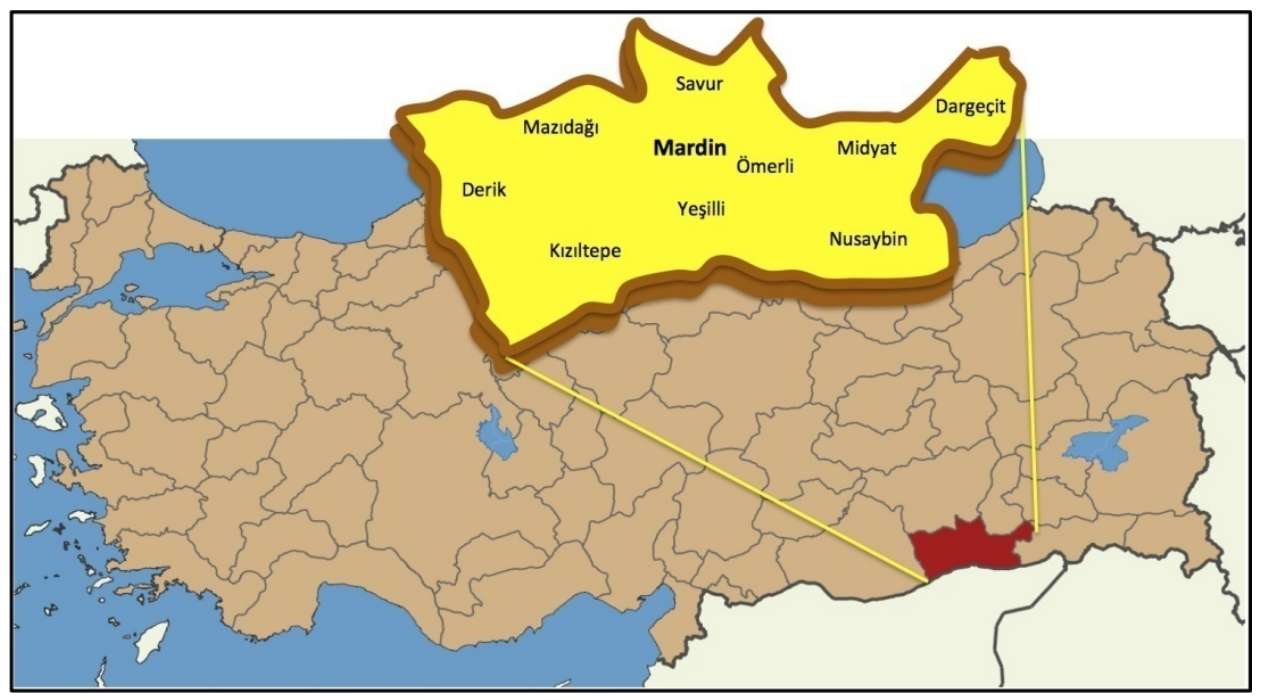

Şekil 1. Mardin ili ve ilçelerinin konumu

Kentin mimari dokusunun tam anlamıyla bölgesel bir merkez olarak 12. yüzyıldan itibaren Artuklular döneminde gelişip biçimlendiği söylenebilir. Bu tarihsel yapı, daha sonraları Akkoyunlu ve Osmanlı dönemlerinde fazla değişikliğe uğramamış, mahallelerin olağan gelişimi ve mesken ağırlıklı sivil mimarisinin yoğunlaşması dışında, genel olarak korunmuştur. Dünyanın Süryani merkezi olarak kabul edilen 5. yüzyılda inşa edilmiş olan Mardin Deyrulzafaran Manastırı; Akkoyunlular döneminde yapılmış olan Kayseriye Çarşısı; XVII. yüzyılda ortalarında inşa edilmiş olan Revaklı Çarşı; V. yüzyılda yapılmış olan Mor Behnam Kilisesi; XII. yüzyılda yapılmış olan Ulu Camii, Artukoğulları tarafindan yapılmış olan Latifiye Camii, XV. yüzyılda yapılan Kasımiye Medresesi ile XIII. yüzyılın ilk yarısında kurulmuş olan Şehidiye Medresesi yöredeki çok sayıdaki tarihi yapılardan sadece bir kaç tanesini oluşturmaktadır (Şekil 2). 


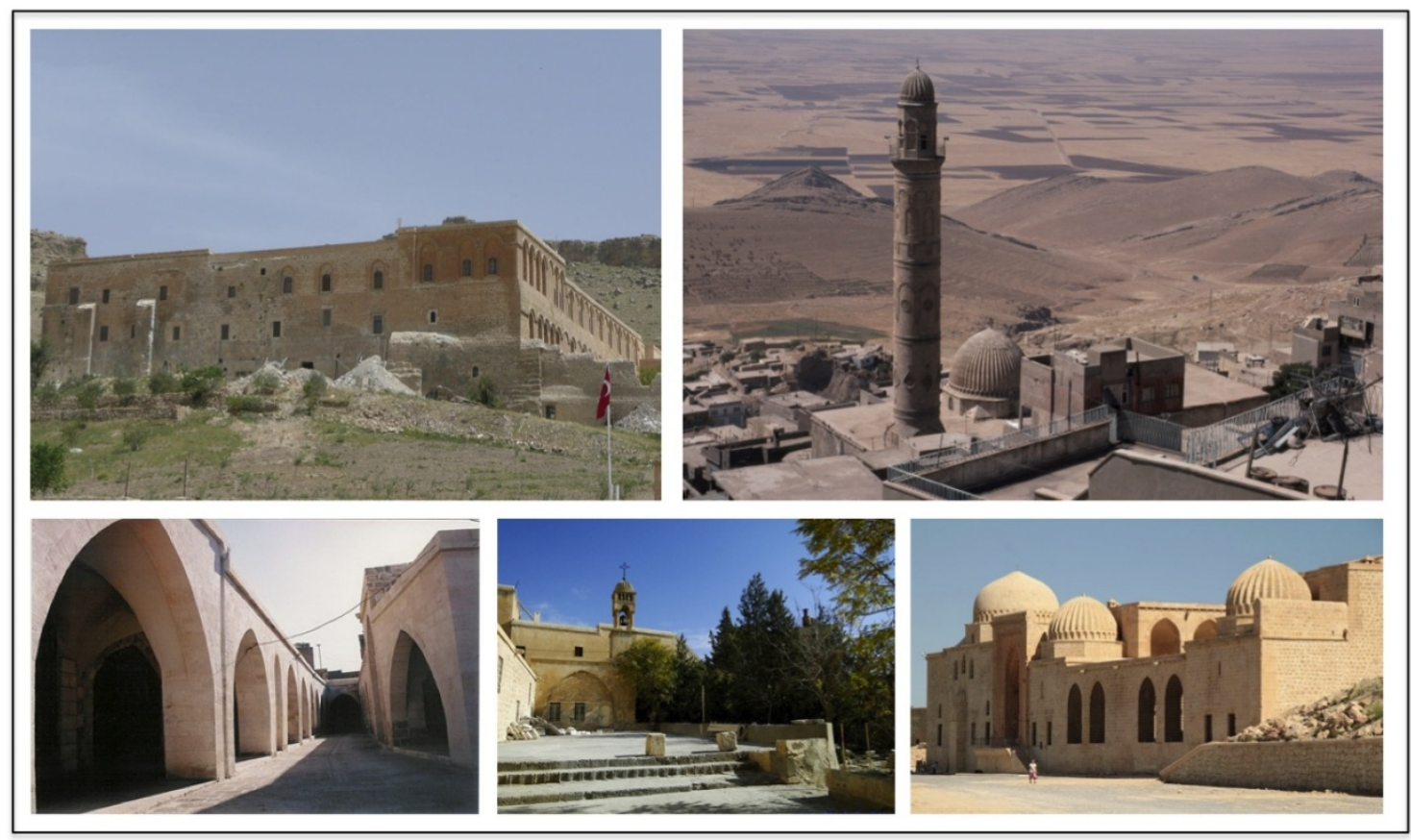

Şekil 1. Mardin’deki tarihsel önemi büyük olan yapılardan Deyrulzafaran Manastırı (üst-sol), Ulu Camii (üst-sağ), Revaklı Çarşı (alt-sol); Mor Behnam Kilisesi (alt-orta) ile Kasımiye Medresesi (alt-sağ), yöredeki çok sayıdaki tarihi yapılardan sadece birkaç tanesini oluşturmaktadır.

Yöre, güneydeki çöl ikliminin (Basra Alçak Basıncı), etkisi altında iken, şehrin kuzeyindeki dağların serin hava kütlelerinin bölgeye girişini engellemesinden dolayı genel olarak karasal iklimin tipik özelliği görülür [1]. Oluşan yüksek basınç alanından dolayı, kış mevsimi soğuk geçerken, yaz aylarında güneyden gelen çöl iklimi etkisi altında olduğu için kurak geçer ve sıcaklığın özellikle temmuz ve ağustos aylarında en yüksek derecelere $\left(40-45{ }^{\circ} \mathrm{C}\right)$ ulaştığ "termik şok" lar özellikle taş eserlerde önce kılcal çatlaklara, sonra de kırılmalara neden olmaktadır. Kış mevsiminden yaz mevsimine geçişin birden bire olması bu termik şokların etkisini artırabilmektedir. Kış aylarında ise sıcaklığın $-14{ }^{\circ} \mathrm{C}$ 'lere kadar düştüğü gözlenmiştir. İlkbahar ve yaz mevsimlerinde bölgedeki bozkır bitkileri kuruduğundan, çöllerden esen rüzgârlar bol miktarda toz taşırlar ve bu toz taşınımını engelleyecek orman örtüsü bulunmadığından il merkezinin ve diğer yerleşim birimlerinin havası saydam değildir. Ayrıca bu taşınan tozların yapı yüzeylerine çarparak aşınmaya yol açtığı da bazı binaların cephelerinde gözlenmektedir.

\section{Materyal ve metot}

Diyarbakır ve Urfa ile birlikte, Güneydoğu Anadolu Bölgesi'nde konut mimarisini en iyi yansıtan yerlerin başında gelen Mardin'deki tarihi yapılarda yaygın olarak silis içeriği oldukça yüksek olan açık renkli beyazımsı sarı renkli kalker kökenli taşlar kullanılmıştır. Bölgedeki taş ocaklarından elde edilen ve kolay işlenen bu taşlardan yapılmış binalarda, herhangi bir sıva malzemesi kullanılmazken, duvarların örülme işleminde taş kırıntılarının kum haline getirilerek kireç ile karıştırılmasından oluşturulan harç ile duvarlar örülmüştür. 
Bölgenin iklimi ve topoğrafyası, Mardin yapılarının inşasındaki en önemli etmenlerdir. Şehrin eğimli tomografik yapısından dolayı hemen tüm yapıların cephesi güneye doğru bakmaktadır. Yine aynı topoğrafik özellikten dolayı, şehirleşme, yatay düzlemde yayılma yerine, düşeyde katlı yapıların tercih edilmesine neden olmuştur.

Mardin kentindeki eski yapıların bozunma durumunun incelenmesi ve saptanması, önceki çalışmalarda edinilmiş normlara bağlı kalınarak geliştirilmiş ve bu fenomonolojik ayrışma kriterlerinin, eserler üzerindeki analizleri ve belgelenmesi yoluyla oluşturulmuştur [2- 4]. Uygulanan araştırı prosesinde iki aşamalı bir metodoloji kullanılmıştır. Çalışmanın ilk safhasında yapıların bulunduğu yerlere gidilerek gözlemler yapılıp, detaylı fotoğraflar çekilerek geçici ayrışma durumu haritası oluşturulmuştur [5]. Araştırmanın ikinci ve son aşamasında ise oluşturulan geçici ayrışma durum haritasının değerlendirilerek [6] fotoğrafların da ayrıntılı incelenmesi ile yapıların ayrışma haritasıyla ilgili çalışmalar tamamlanmıştır.

\section{Mardin eski yapılarındaki bozunma türleri}

Doğal yapı taşları, dayanıklılığın ve sürekliliğin sembolü olarak bilinmekle beraber farklı kullanım alanlarına ve yerlerine bağlı olarak çevresel faktörlerin etkisiyle fiziksel, kimyasal ve biyolojik bozunmaya uğrarlar [7-17]. Yapıtaşı olarak kullanılmış kayaçlardaki ayrışma, fiziksel etkiler nedeniyle gelişebileceği gibi taşı oluşturan mineraller arasındaki bağlayıcı maddelerin kimyasal etkenlerle bozunarak ortadan kalkması sonucu da oluşabildiği gözlenmiştir. $\mathrm{Bu}$ nedenle taşlardaki ayrışma, çoğunlukla birbirine ortam hazırlayan kimyasal ve fiziksel süreçler olarak iki kategoride gerçekleşir. Bunlara ek olarak havanın bileşimindeki gazlar ile su, isi ve organik maddeler de ayrışma sürecini hızlandıran faktörlerdir. Soğuk ve kurak bölgelerde fiziko-mekanik ayrışma ön planda iken, nemli ve sıcak bölgelerde ise kimyasal ayrışma ön plandadır ve bozunma hızı fiziksel sürece göre daha fazladır.

Mardin'in eski yapılarında da her iki süreç gözlenmektedir ve özellikle olumsuz meteorolojik koşullarının hava kirliliği ile birlikte hareket etmesi sonucunda, zamanla taş yapıların renginin değiştiği ve üzerlerinde bulunan bazı motiflerin aşınarak silikleştiği görülmektedir. Kentteki tarihsel yapıların bir çoğunda bitki ve mikroorganizmaların neden olduğu biyotik etmenler ile su, güneş ve rüzgârın neden olduğu abiyotik etmenlerin bozunmaya neden oldukları saptanmıştır. Yapılarda gözlenen bozunmalar genel olarak taştaki çatlak oluşumu, yüzeydeki materyal kaybı, taşlardaki renk değişimi ve yüzeydeki kirlilik ile bitkilerin neden olduğu Biyoalterasyon olarak sınıflandırılabilir. Taş yapısında oluşan çatlakları değişik formlarda ve boyutlarda görmek olasidır.

Fiziksel, kimyasal ve biyolojik ayrışma süreçleri birbirleriyle etkileşerek gelişirler. Fiziksel ayrışma süreci taşları daha küçük parçalara ayırarak, yüzey alanını arttırır ve böylece kimyasal ayrışmaya zemin hazırlayarak hızlandırır. Aynı durum kimyasal ayrışmanın mineralleri güçsüzleştirerek fiziksel ayrışmaya yardımcı olması ile yinelenir. Biyolojik ayrışmanın elementleri bitki ve mikroorganizmalar ise kök uzatarak parçalama, bakteri ve asidik solüsyon üreterek çözme v.b. gibi hareketlerle her türlü ayrışmayı hızlandırır. 
Doğal etmenlerin yanında, antropojenik etmenler olarak adlandırılan ve insanların bilinçli ya da bilinçsiz olarak neden oldukları bozunma da Mardin'de yoğun olarak gözlenmiştir. Özellikle; bakımsızlık, terk, kasıtlı tahrip gibi eylemlerle Mardin'de bulunan anıtların ve tarihi yapıların zaman içerisinde bozunma sürecine girdikleri gözlenmektedir.

\subsection{Fizikomekanik bozunmalar}

Taşın iç yapısına ya da dış etkilere bağlı olarak, çeşitli derecelerde yüzey kayıplarına yol açan fizikomekanik bozunmalar sonucunda taş yüzeyi, su veya nemden dolayı, rüzgârın da yardımıyla 1slanma-kuruma gibi nedenlerle önce pürüzlü hale gelir ve ardından da zayıflamaya ve gevşemeye başlar. İleriki süreçlerde taş yüzeyi yıkandıkça çözünüp erimeye başlar ve aşınmaya devam eder. Yüzeyden materyal kaybı olarak adlandırılan bu ayrışma, taşın bir bölümünün, gerisinde meydana gelen çeşitli etkiler nedeniyle ana kütleden ayrılmasıdır. Bu etkiler, taşın içyapısında bir basınç oluşturarak, önce çatlaklara yol açar, ardından zayıflayan parçayı itmeye başlayarak taş özgün yüzeyinden $1-8 \mathrm{~cm}$ arasinda materyal kaybetmesine neden olur.
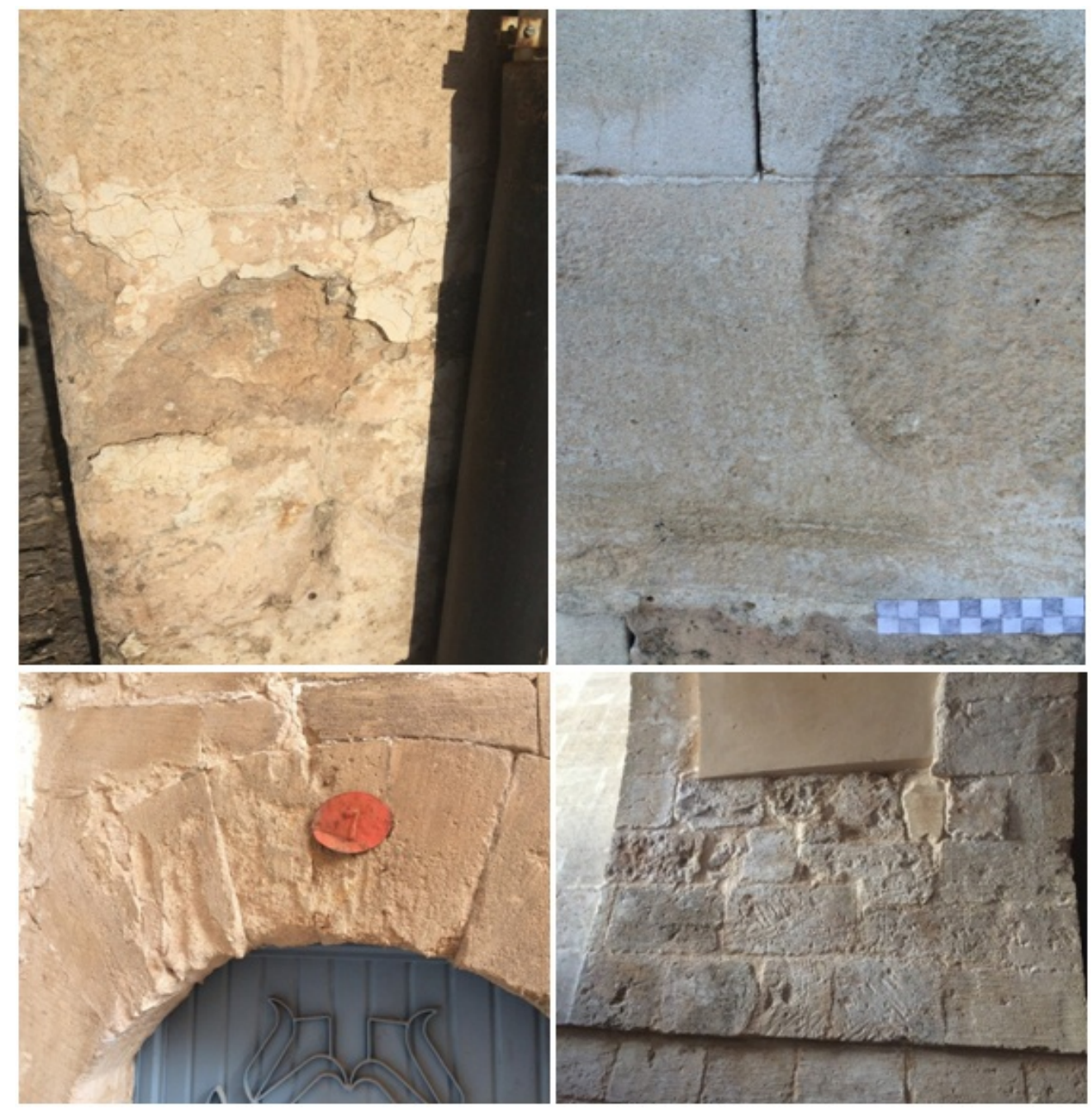

Şekil 2. Sicaklık değişmeleri ve kimyasal ayrışma olayları sonucunda kaya kütlelerinin ince katlar şeklinde taşın yüzeyine paralel levhalar halinde ayrışması (üst-sol), dağılma şeklinde ayrışma (üst-sağ), granüler çözünme (alt-sol) ve alveolar ayrışma şeklindeki materyal kayıpları. 
Mardin yapılarındaki yüzeyden materyal ayrılması, kabarma, tabakalaşma, soyulma ve kabuklaşma şeklinde kendini göstermektedir (Şekil 3). Bu türdeki bozunmada, taşta yüzeysel bir aşınma meydana geldiği ancak henüz taşın yapısal özelliğini bozacak derecede bir kayıp gerçekleşmediği görülmüştür.

Yüzeyden materyal kaybı, taşın kullanıldığı yere ve boyutlarına göre değiştiği, bazı durumlarda ise de bir yapısal hasar oluşturduğu görülmektedir (Şekil 4). Genel olarak yüzey kaybının derinliği arttıkça hasarın derecesinin de arttığı; taşın boyutlarının giderek küçüldüğü gözlenmiştir. Bu sürecin sonucu olarak, taş kesitinin daralması sonucunda taşın zamanla işlevini yitirmeye başlaması sıklıkla görülen bir bozunma türüdür. Yapılarda, kap1 ve pencerelerde kullanılan demirden yapılmış elemanların paslanarak genişlemesi sonucunda taşı patlatarak bazı parçaların zayıflayıp düşmesine neden olması bu tür bir bozunmaya en iyi örnektir.
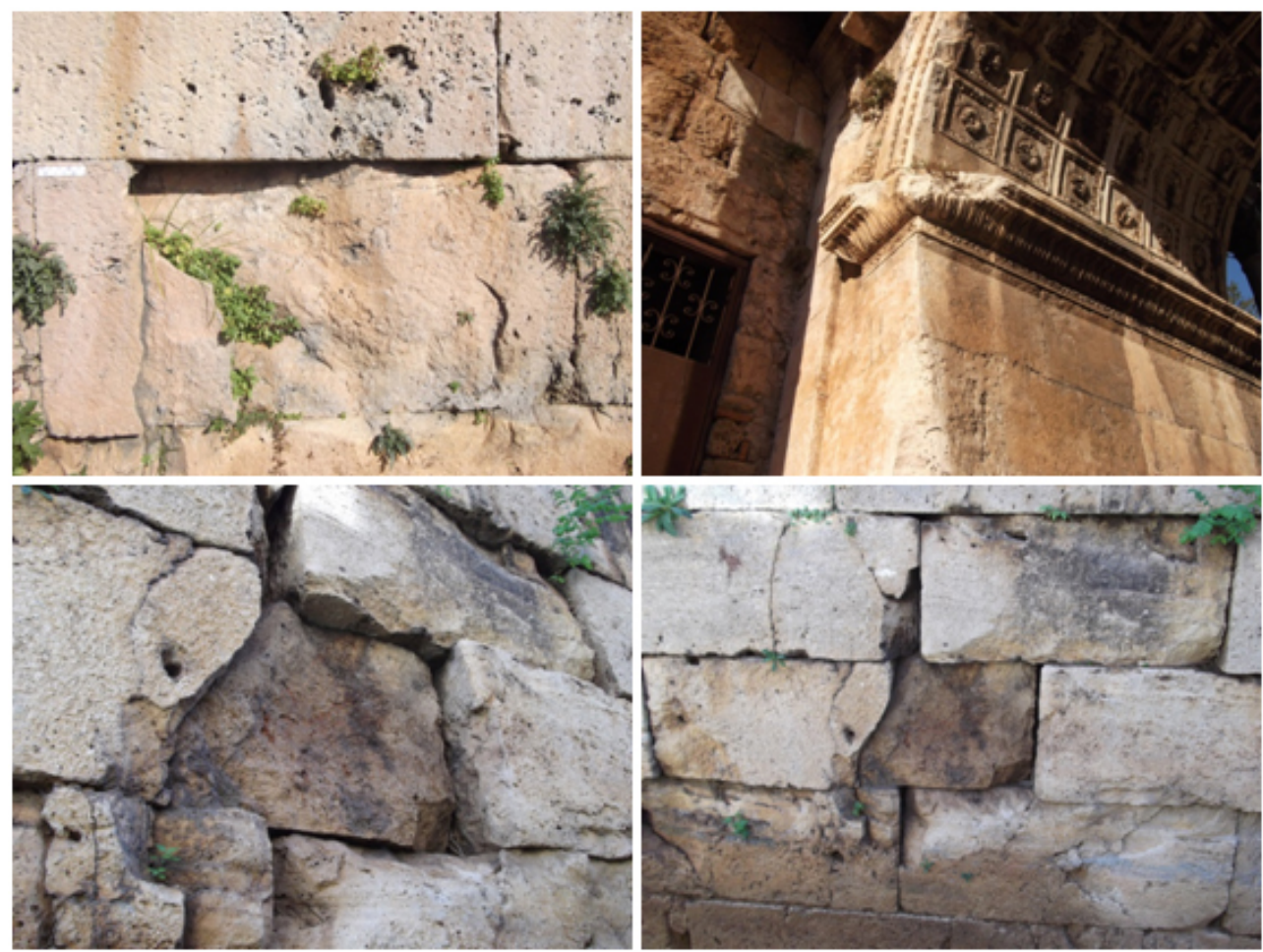

Şekil 3. Mardin'deki bazı yapılarda, yüzeyden materyal kaybı kendini oldukça belirgin şekilde göstermektedir. Bazı yapılarda, taşın iç basıncından dolayı düzgün olmayan parça ayrılması olarak görülen "patlama” şeklindeki ayrışma sonucunda taşın özgün yapısını tümüyle kaybettiği ve binanın duvarlarında zayıflamaya neden olduğu gözlenmiştir.

Taş yüzeyinde, değişken şekil ve büyüklükte birbirine bağlı olarak gelişebilen boşluklar şeklinde oluşan alveoler ayrışma veya arı peteği şeklindeki ayrışma yine kentteki tarihsel yapılarda sıklıkla rastlanan bir ayrışma türü olarak gözlenmektedir (Şekil 5) ve büyük bir olasılıkla taşın fiziksel veya kimyasal özelliklerinin homojen olmayan düzensizlikleri nedeniyle oluşan bir ayrışma türüdür. Mardin yapılarındaki bu tür boşlukların boyutları genelde santimetre boyutunda kalmaktadır. 

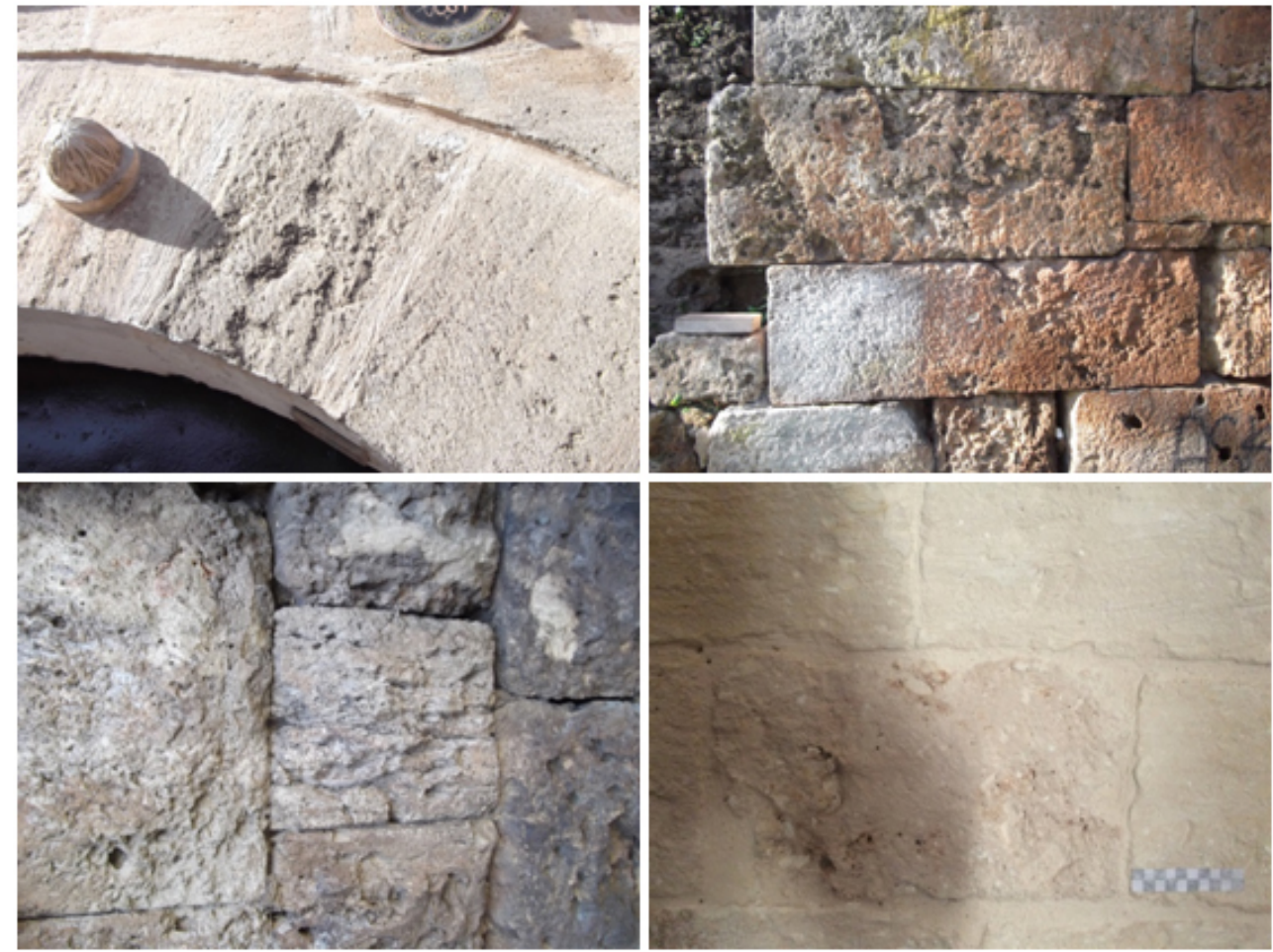

Şekil 4. Mardin'deki tarihi yapılarında gözlenen değişik form ve boyuttaki alveolar ayrışma örnekleri ile taşın içerdiği minerallerinin ayrışması yoluyla veya dış biyolojik etmenlerden dolayı, taşın orijinal renginin değişime uğraması sonucunda oluşan renk değişimi şeklinde bozunma (üst-sağ).

Alveolar bozunmanın bir alt grubu olan çukurlaşma veya oyuklanma (Şekil 6), birbirleriyle bağlantılı olmadan gelişen alveolar ayrışmadır. Taşların üzerinde yada aralarında görülebilen, boşluk ya da delik olarak ta bilinen bu ayrışma, çeşitli boyutlarda olabilir. Bir elemanın monte edilmesi amacıyla taş yüzeyinde açılarak daha sonra kapatılmamış olan bir delik, örgüyü oluşturan bir elemanın yerinden düşmesiyle oluşan boşluklar veya örgüde meydana gelen bir kesinti bu grupta ele alınabilir. Bu boşluklar, suyun rahatlıkla toplanabileceği yada bitkilerin gelişebileceği alanlar oldukları için sakıncalıdırlar. Boşluğun çevresindeki taşlar, hasar verici hava etkilerine açık ve daha korumasız hale gelirler; bu nedenle, diğer bozunma süreçlerini de hızlandırıcı etkisi vardir.

Özellikle fosilli ve taneli yapıda olan doğal taşlarda gözlenen bir bozulma türü olan oyuklanma, atmosfer etkileri nedeniyle iri tanelerin zayıflayarak yerinden çıkmasıdır. Böylece taş yüzeyinde gelişigüzel oyuklar meydana gelir. Oyuklar nedeniyle yüzeyin boşalması iki yönden zarar vericidir: Yüzey kaybı nedeniyle taşın kesiti küçülür. Ayrıca yüzey oyuklandığında bozunma alanı artmış olur, taşın yıpranması hızlanır. 

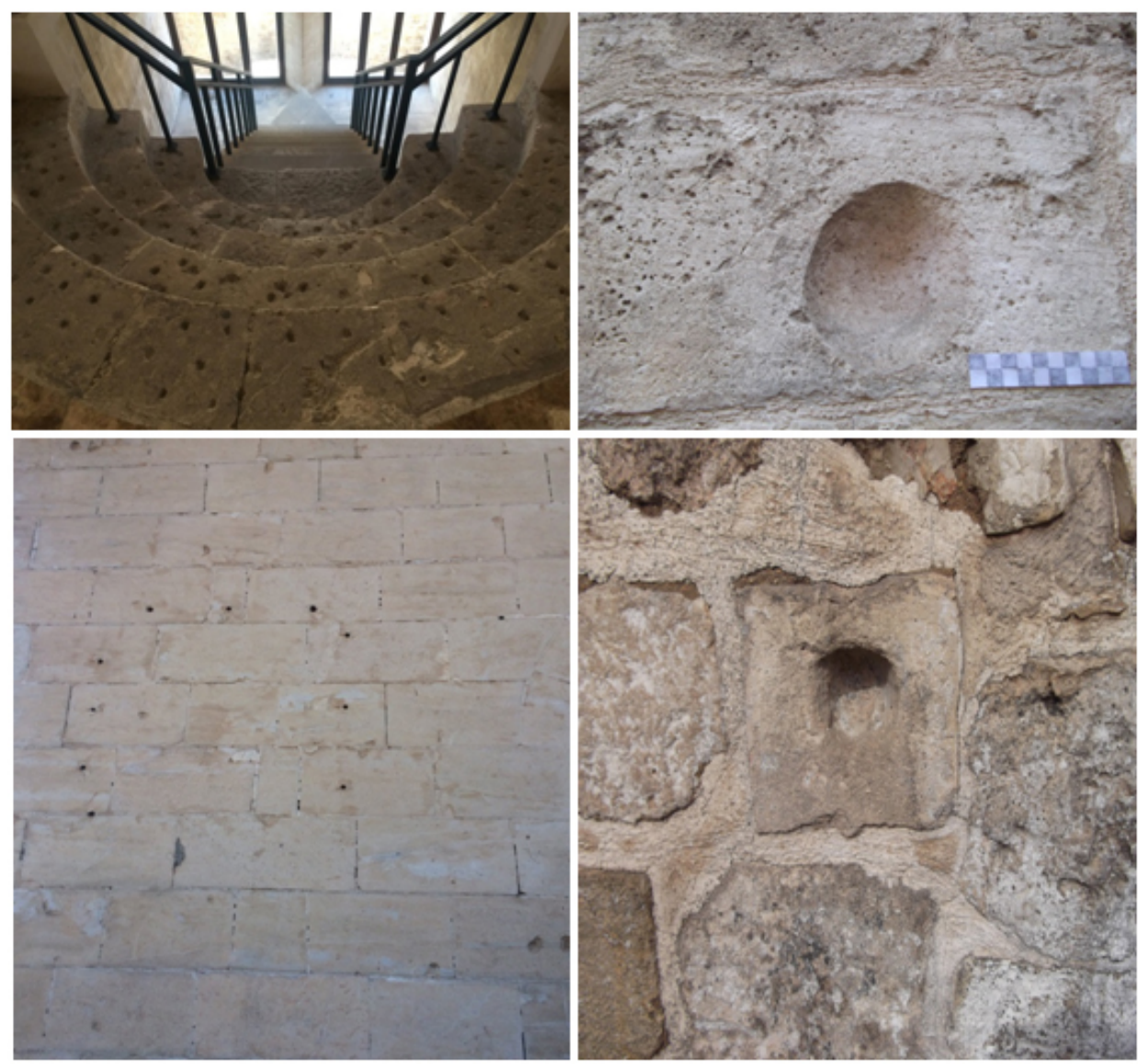

Şekil 5. Bazı tarihsel önemi büyük olan yapılarda gözlenen oyuklanma şeklindeki bozunmaya örnekler.
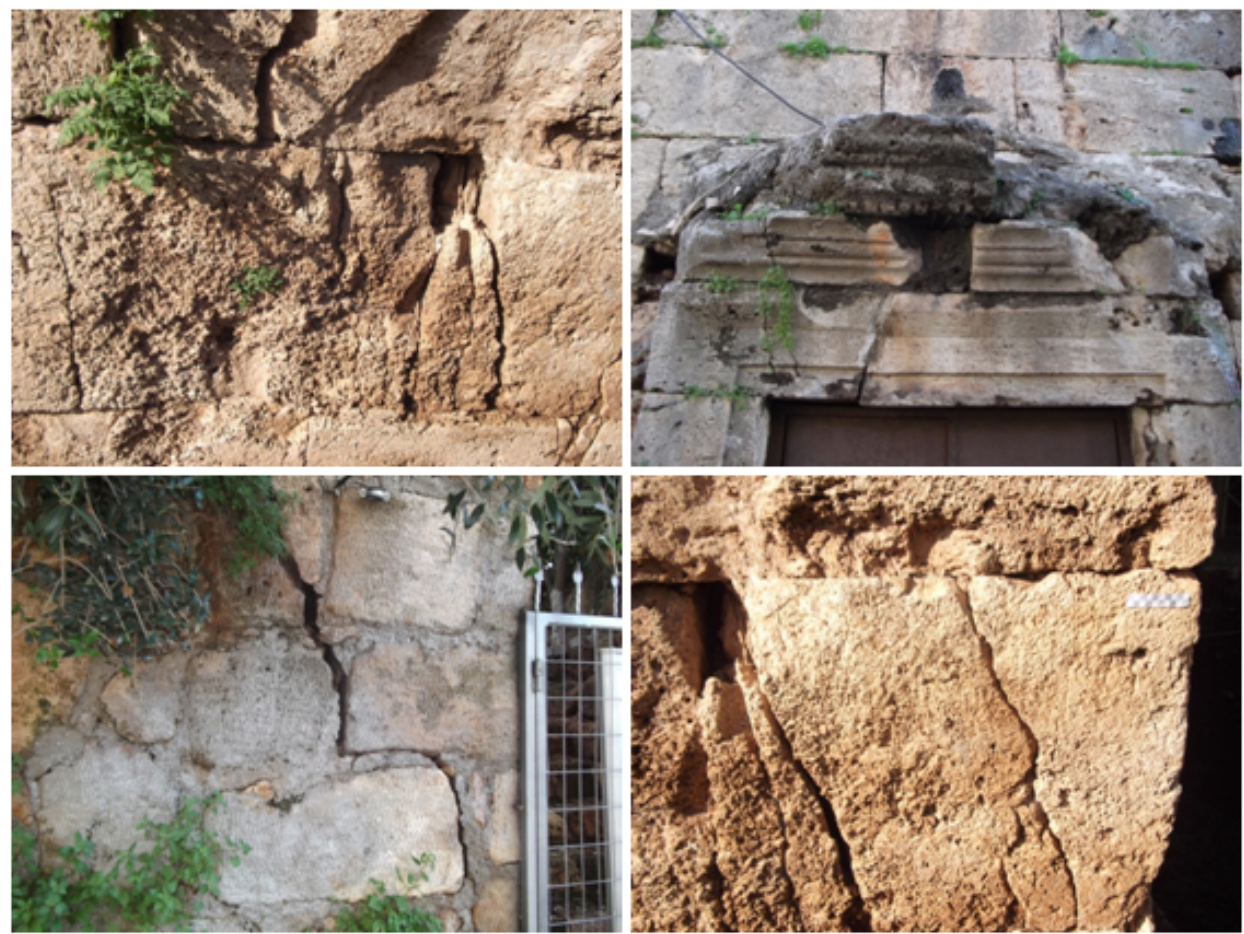

Şekil 6. Mardin'deki tarihsel yapılarda gözlenen, taşta çeşitli nedenlerden dolayı oluşan (kılcal, tek çatlak veya çatlaklar sistemine örnekler. 
Yapıtaşlarında, taşın orijinal yapısında bir eksilme söz konusu olmadan, taşın kendi yapısında oluşan değişmeler sonucundaki çatlaklar oluşabilmektedir. Taşta, tozu ve nemi içine çekmesi sonucunda taş yüzeyini ve kesitini çaprazlamasına geçerek ince, kılcal çatlaklar oluşması yine bir ayrışma türü olarak nitelendirilmektedir. Mardin'deki yapıların hemen hepsinde gözlenen bu çatlaklar sistemini, bazen taş yapısını izleyerek bazen da taş yapısından tamamen bağımsız gelişerek eserlerde kırılmaya neden oldukları gözlenmiştir (Şekil 7). Bu çatlakların olasılıkla zeminin stabil olmayışı sonucunda yapının oturması veya kazı yapılması gibi mekanik nedenler ya da taşın gerisindeki bir metal elemanın paslanıp genişlemesi gibi baskı yapıcı etkiler sonucunda oluştuğu düşünülebilir.
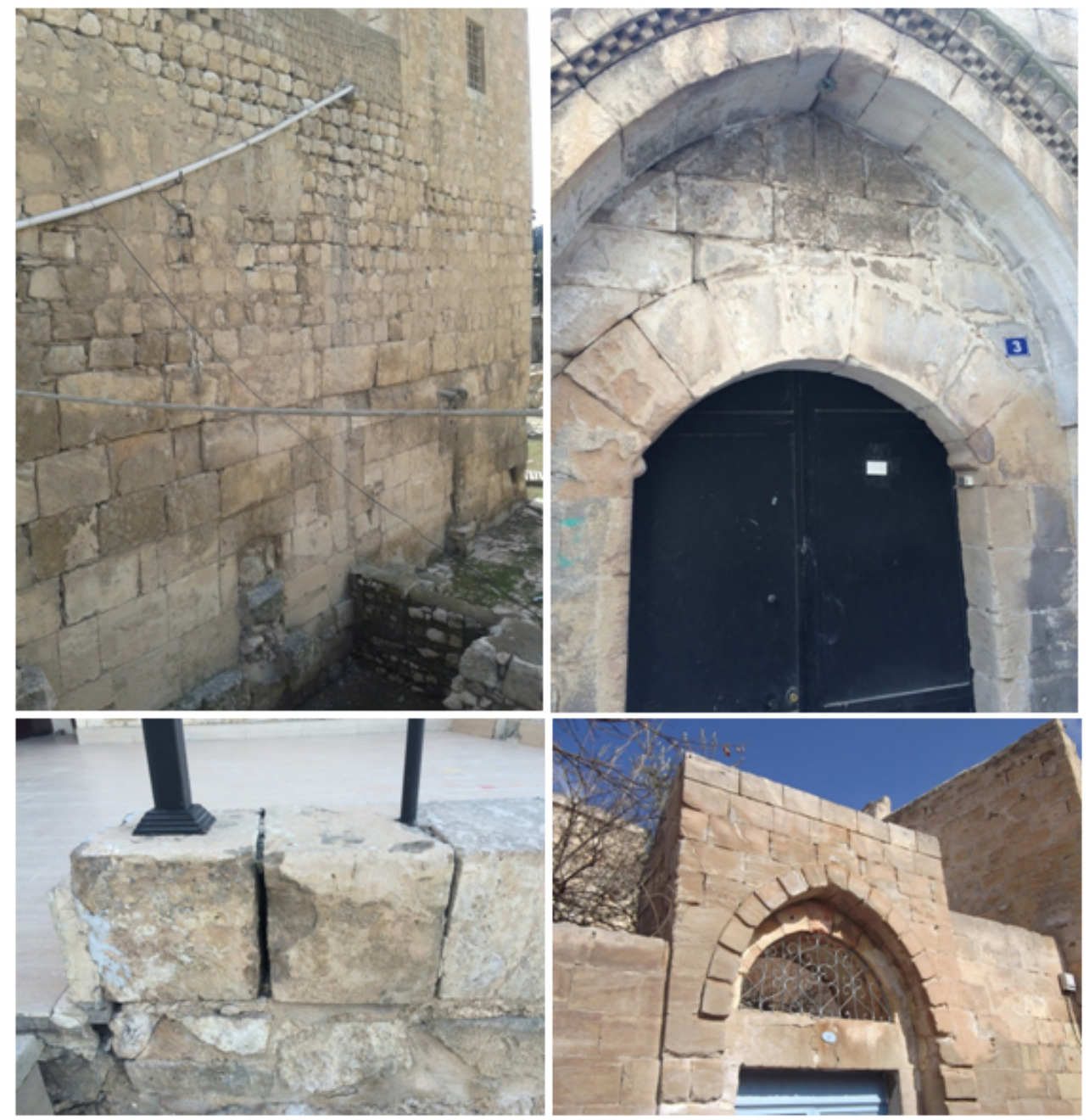

Şekil 7. Birçok tarihsel yapıda gözlenen derz boşalmasıyla ilgili ayrışma türlerine örnekler.

Duvar örgüsünde kullanılan taşlar, çeşitli kalınlıklarda derz oluşturacak şekilde yerleştirilir ve harçla birleştirilirler. Derz harçları, özellikle yıkanma sonucunda zayıflayıp çözünerek taşlardan ayrılabilir. Bu durumda, taşların arasındaki derzlerde yer yer çeşitli derinliklerde boşluklar meydana gelir. Derz boşalması, aşların alt ve üst yüzeylerinin de açıkta kalması nedeniyle başka bozunmaları da hızlandırabilir. Mardin'deki birçok eski yapıda gözlenen derz boşalması (Şekil 8), daha sonra ikincil sorunlara temel oluşturmaktadır ki bunlar arasında en sık görüleni, boşluklarda meydana gelen bitkilenmedir. 
Taş yüzeyinde, taşla ilgisi olmayan yabancı materyal birikimi olarak gözlenen ve genellikle hava kirliliğine bağlı olarak ortaya çıkan, gri renkli ve yüzeyde ince bir tabaka halinde görülebilen oluşumlar olarak ortaya çıkan kirlenme yine Mardin'deki yapılarda, özellikle şehir merkezinde bulunan yapılarda önemli diş görünüş alterasyonuna neden olmaktadır (Şekil 9). Taş yüzeylerin yağmur suyu ile yıkanabilen bölümlerinde oluşan, genellikle ince, süreksiz ve yüzeysel kirlilikler, atmosferdeki çok yapışkan özellikleri olmayan toz, kül ve is partiküllerinin, homojen olmayan gri renkten siyaha varan renklerde taş yüzeyinde birikmesinin bir sonucudur. Taşın cinsine ve kirliliği oluşturan kaynağa bağlı olarak; kirin rengi, yapısı ve yüzeyle ilişkisi de değişir. Özellikle gözenekli yapıdaki doğal taşlarda oyuklarda biriken kirlilik, önemli ve temizliği zor bir bozunma şeklidir. Kirliliğin durumuna ve taşın cinsine göre, temizleme yöntemi de farklılaşmaktadır.

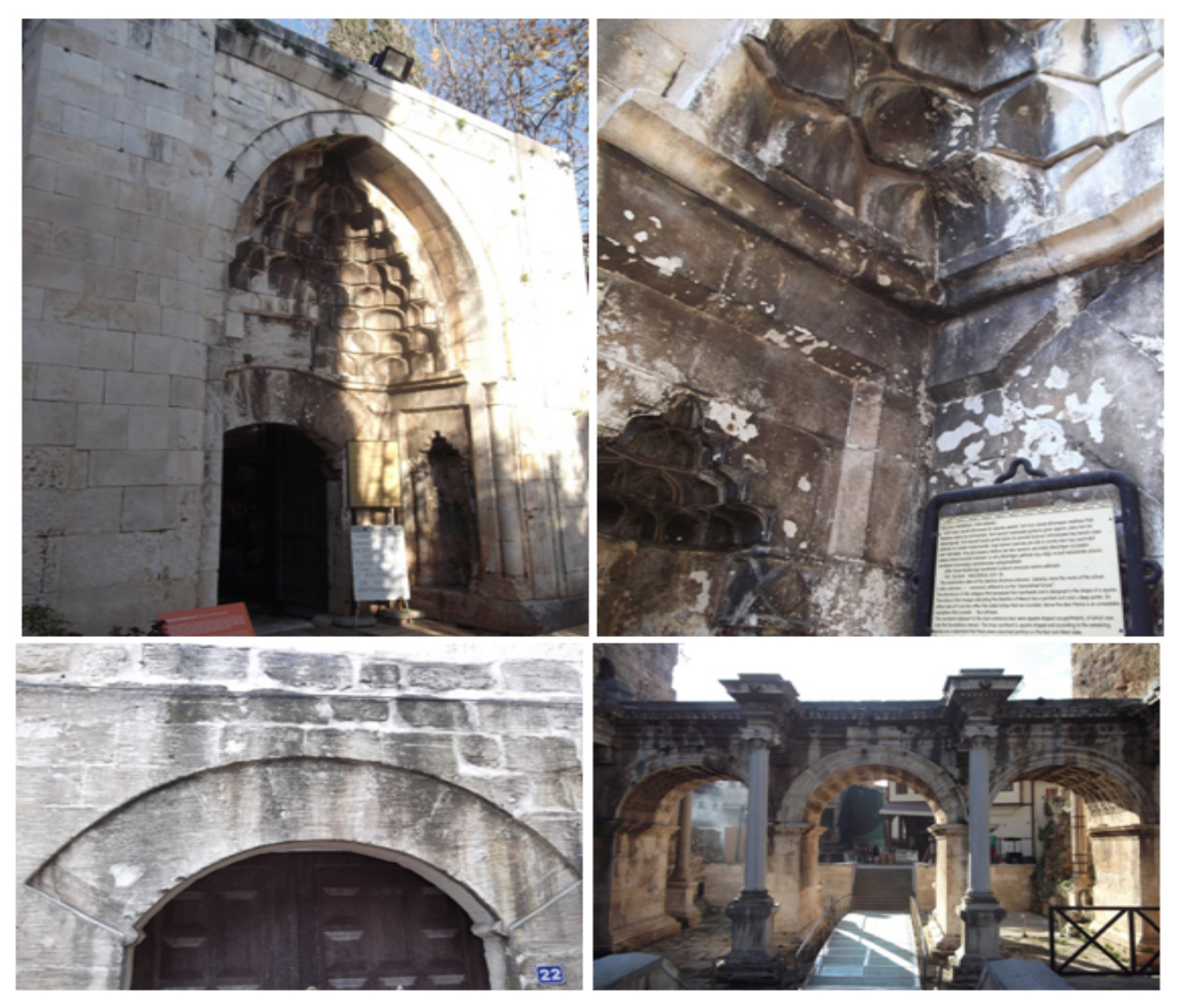

Şekil 8. Özellikle şehir merkezine yakın olan yapılarda sıklıkla görülen atmosferik kirlenme, yoğun şekilde kendini hissettirmektedir.

Her ne kadar ilin meteorolojik ve tomografik yapısı hava kirliliğinin yayılmasını engelleyecek özellikte olmasına karşın özellikle kent merkezinde yaygınlaşan hızlı nüfus artışıyla birlikte düzensiz kentleşmeye ek olarak kalitesiz yakıt tüketimi hava kirliliğine neden olmaktadır [1]. Kentte, hava kirliliğine neden olan etkenlerden birisi de motorlu araçlardan kaynaklanmaktadır. Artan nüfusa bağlı olan araç sayısının artışı, yapılarda gözlenen kirlenme ürünlerinin yoğunlaşmasına neden olmaktadır. Ayrıca şehirdeki en önemli sanayi kuruluşlarından olan Mardin Çimento Fabrikası ile Mardin Kireç Fabrikasından çevreye yayılan kirleticiler ve partiküller ildeki emisyon yükünün önemli iki bölümünü oluşturmaktadır. Çapları 0,3 - 0,6 mikron arasında değișen bu partiküller hava kirliliğinin en iyi bilinen etkisini tarihi bina cephelerinde göstermektedir. 


\subsection{Biyolojik bozunmalar}

Biyolojik yerleşim (gelişme, kolonizayon) adı altında değerlendirilen, yapıların yüzeyinde likenler ve yosun gibi mikroflora ile ot türündeki bitki gelişimi, Mardin yapılarında gözlenen diğer bir bozunma türüdür. Rüzgarla taşınarak duvar örgüsü içindeki ufak boşluklara, derz aralarına veya taşların içindeki boşluklara yerleşen tohumların, zaman içinde büyüyerek bitki haline gelmesidir. Bir biyolojik bozulma türü olan bitkilenme, duvarlarda, ya da çatı örtüsünde ortaya çıkabilir. Özellikle kullanılmayan yapılarda yoğunlukla gözlenen biyoaşınma, bazı durumlarda yalnızca yüzeyde büyüyen otlar halinde sararak ağaç şeklinde geliştiği de gözlenmiştir (Şekil 10). Bazı durumlarda, giderek büyüyen bitki köklerinin, çevresindeki taşlarda çatlak, parça kopması gibi başka bozunmalara da yol açtığı saptanmıştır.
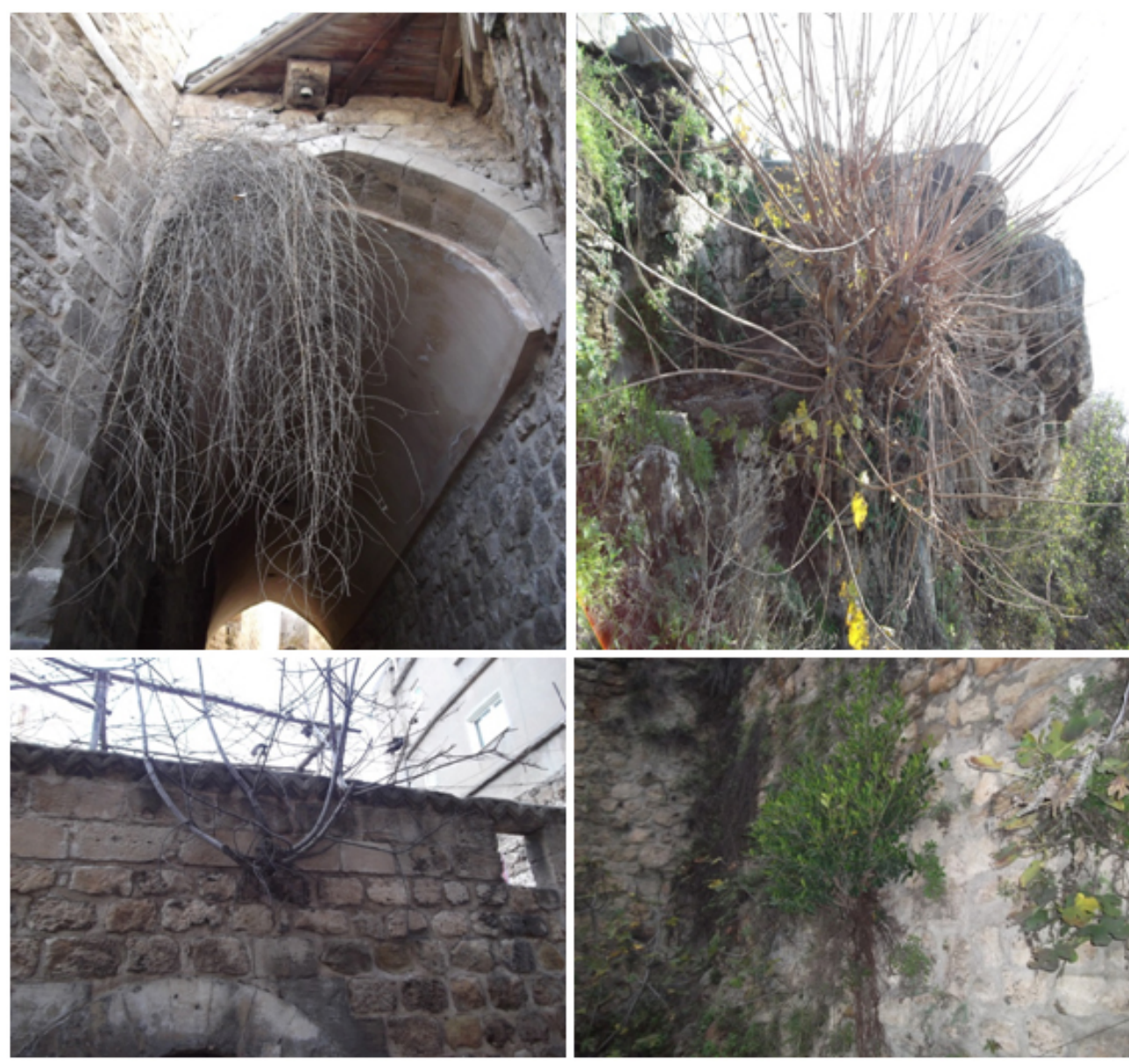

Şekil 9. Mardin'deki artık kullanılmayan yapılarda çok rastlanan bitki yerleşimine ait örnekler.

Kara yosunları ve su yosunları (algleri) gruplarını kapsayan genel bir terim olan yosun oluşumu birçok eski yapıda gözlenmektedir. Mardin'de, yine birçok diğer kentte sıklıkla görüldüğü gibi çoğunlukla temelden yükselen suyun ya da çevre koşullarının etkisiyle, duvarların zemine yakın bölgelerinde ve gölge alan bölümlerinde kolonileştikleri ve zamanla taş yüzeyinde çukurlaşmalara ve çatlaklara neden oldukları saptanmıştır. Yosunlar, ayrıca yüzeyi kaplayarak gerisindeki duvar örgüsünün nefes almasını engellediğinden ve sürekli neme sebep olduklarından, oksidasyon-redüksiyon reaksiyonlarını hızlandırarak duvar yapıtaşlarını yıpratabilmektedirler. 

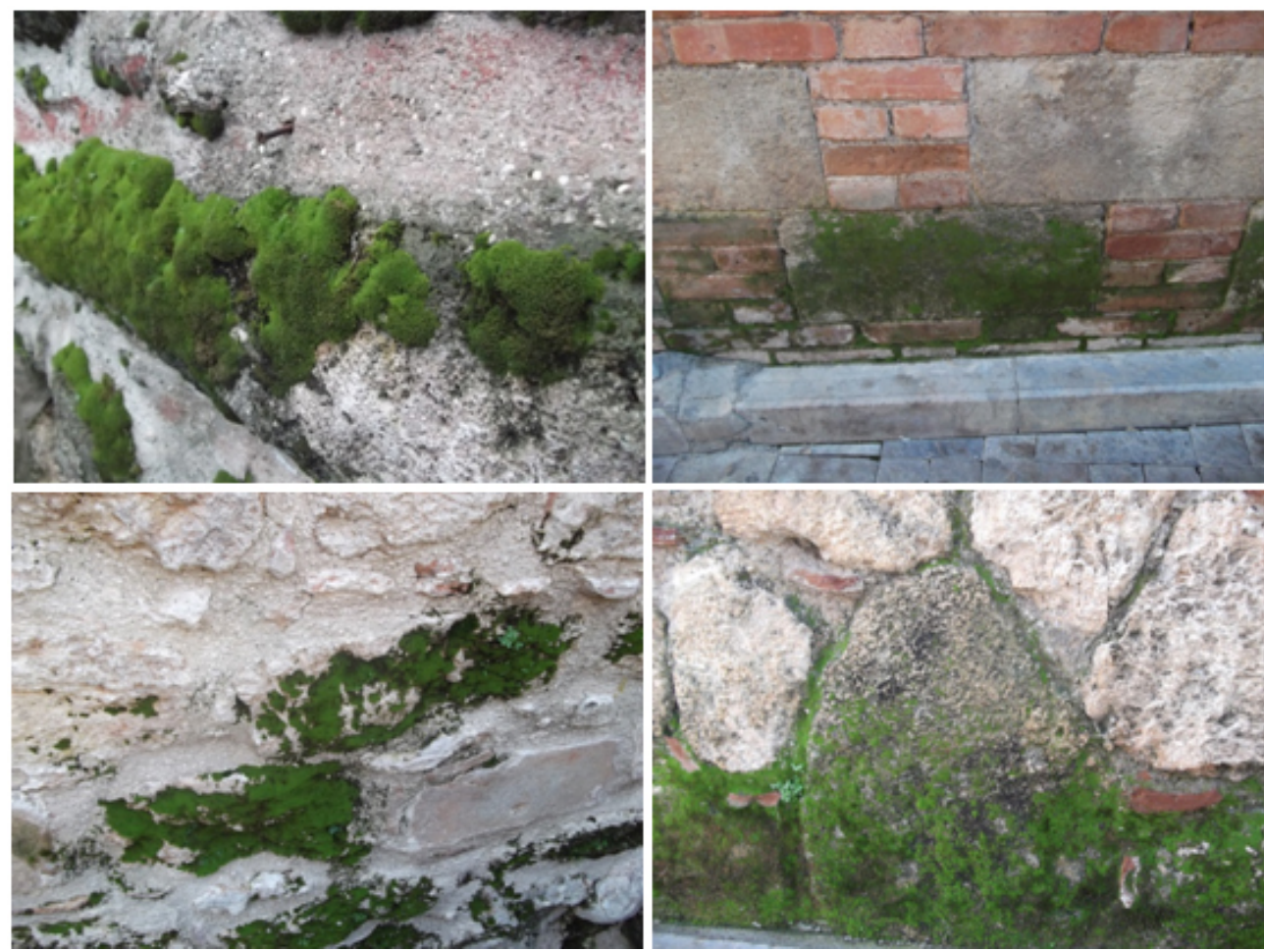

Şekil 10. Mardin'deki özellikle şehir içindeki yapılarda gözlenen yosunlaşmanın 1-2 milimetre arasında değiştiği gözlenmiştir. Yosunlar, ayrıca salgıladığı asidik enzimlerle taşı ayrıştırarak taş yüzeyi ile kendi gövdesi arasında ince bir toprak tabakası oluşturmaktadır.

\subsection{Insanların oluşturduğu bozunmalar}

Tüm ülkede yaygın olarak rastlanan antropojenik etmenlerin başında, onarım amaciyla yapılan müdahaleler gelmektedir. Mardin'deki bir çok yapıda çimento ile yapılan dolgu, tamamlama gibi uygulamalar, taş yüzeylerin boyanması, sıvanması ya da kaplanması gibi restorasyon denemeleri gözlenmektedir (Şekil 12). Özellikle birçok yapıda gözlenen çimento kullanımın bir sonucu olarak orijinal malzemenin çatladığ 1 görülmüştür. Çimentolu harç ile temas halinde olan taş yüzeylerinde, tuzlanma ve parçalanma gibi bozunmalara rastlanılmıştır. Yine buna bağlı olarak, çimentonun nefes alan bir malzeme olmaması nedeniyle kapladığı taş yüzeyinin kurumasını geciktirmesi sonucu taşın iç kesimlerinde oluşan bozunma ve ayrışmaların gerçekleşmiş olma olasılığı oldukça yüksektir.

Kasıtlı tahrip anlamına gelen vandalizm, günümüzde sosyal ve psikolojik bir sorun olup eski eserlerin bozunmaya uğramasındaki diğer bir etmendir. Mardin'in şehir içerisindeki hemen tüm yapılarında, yapı duvarlarını oluşturan taşların üzerine sonradan yapıştırılan çıkartmalar ve duyurular, metal hane numaralarının yanında grafiti uygulamaları sonucunda yapıların orijinal görüntüsüne zarar verdiği gözlenmiştir. 

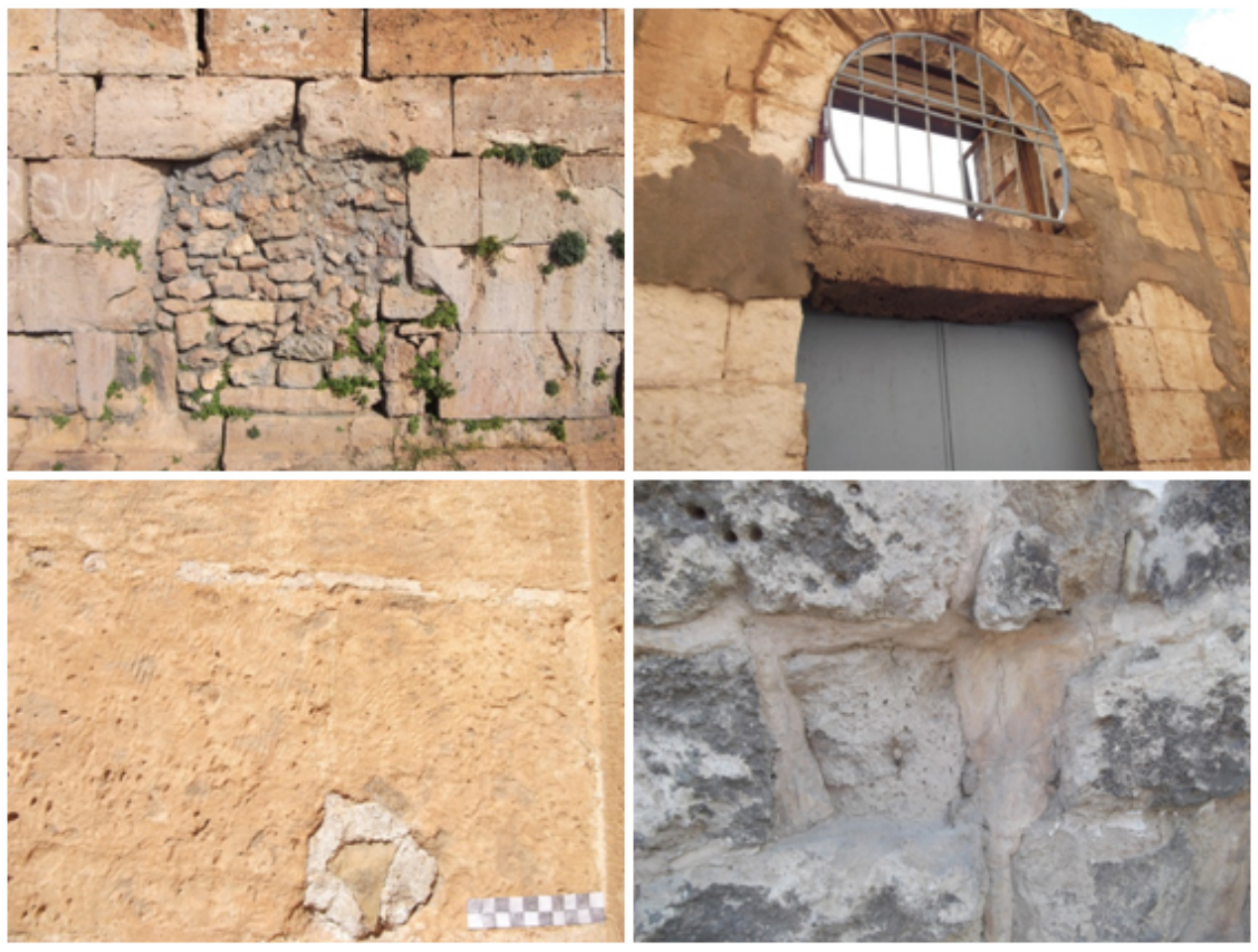

Şekil 11. Restorasyon amacıyla taşın çatlamasından sonra kırılarak ayrılmasının engellenmesi için çatlak bölümün çimento ile doldurularak onarılması.

\section{Sonuçlar}

$\mathrm{Bu}$ çalışmada, taş yapıların ve eserlerin korunması üzerine yapılan araştırmaların sonuçlarının değerlendirildiği çeşitli kaynaklardan yararlanılmış, koruma üzerine yapılan çalışmaların derlemelerinden, kitap ve benzeri kaynaklarda elde edilen veriler toplanarak, ilgili alanında önemli bilgiler sunulmuştur. Yayınlanmış çalışmaların sentez ve meta analizlerini de kapsayan eleştirel bir değerlendirme çalışması olmasının yanında, önceki araştırmaların bütünleștirilmesi ve değerlendirilmesi yoluyla problemlerin açıklanmasına yönelik gelişmeler sunulmuştur.

Her bozunma türünün gerektirdiği onarım yöntemi ve uygulama koşulları farklıdır. $\mathrm{Bu}$ nedenle, bozunmalar türlerine göre net ve doğru bir şekilde sınıflandırılabilirse, hasar verici etkilerin nasıl ortadan kaldırılacağı ya da azaltılacağı belirlenebilir. Bozunma türlerini sınıflandırırken uluslararası alanda kabul görmüş terimleri kullanmak çalışmaların ortak dilde olması için önemlidir.

Eserlerin bozunma nedenlerinin kaynağının araştırılarak saptanması, eski eserleri koruma ilkeleri açısından, konservasyon uygulamalarının seçimi ve kararı için en önemli ilk adımı oluşturmaktadır. Günümüze kadar yapılmış ya da hali hazırda devam eden birçok onarım çalışmalarında; özgün taşın özelliklerinin yeterince tanınmaması, bozunma türlerinin doğru tespit edilememesi, edilse dahi bozunma faktörlerinin belirlenememesi, hasara uygun koruma uygulamasının seçilememesi, yanlış malzeme seçimi gibi sayılabilecek daha birçok hata sonucunda tarihi yapıların görünüşünün zedelendiği ve yapının özgün ayrıntılarının yok olduğu literatürde sıkça şikayet konusu olmuştur. $\mathrm{Bu}$ tür sorunların önüne geçilebilmesi ve onarımların daha bilinçli 
yapılabilmesine yönelik bir amaçla hazırlanan bu makale, ayni zamanda Mardin kentindeki tarihsel değerleri çok büyük olan taş eserlerin koruma uygulamalarında yararlanılabilecek bir kaynak oluşturmaktadır.

Başarılı bir koruma uygulamasının, başta taşın cinsine, daha sonra taşta görülen bozulmalara ve sağlamlaştırmada kullanılacak ürünlerin türüne, uygulama tekniğine, penetrasyon kabiliyetine ve durabilitesine bağlı olduğu unutulmamalıdır. Ayrıca, taş eserlerin temizlenme, onarılma, sağlamlaştırma ve koruma aşamalarından sonra düzenli aralıklarla bakımlarının yapılması halinde eserlerin daha uzun süre yaşamaları sağlanabilmektedir. Böylece kültür mirasımız olan taş eserler gelecek nesillere kazandırılabilir.

\section{Kaynaklar}

[1] Mardin Valiliği, Çevre ve Şehircilik İl Müdürlüğü, Çevre Durum Raporu, Mardin, (2011).

[2] ICOMOS-ISCS, 200ICOMOS-ISCS: Illustrated Glossary on Stone Deterioration Patterns, Paris, (2008).

[3] Fitzner, B., Heinrichs, K. \& Kownatzki, R., Weathering forms at natural stone monuments -classification, mapping and evaluation. International Journal for Restoration of Buildings and Monuments, 3, 2, 105-124, (1997).

[4] Öcal, A.D., Dal, M., Doğal Taşlardaki Bozunmalar, Mimarlık Vakfi İktisadi İşletmesi, İstanbul, (2012).

[5] Fitzner, B., Documentation and evaluation of stone damage on monuments. - In Kwiatkowski, D. \& Löfvendahl, R. (ed.): Proceedings of the 10th International Congress on Deterioration and Conservation of Stone, Stockholm, ICOMOS, Sweden, 27 June - 2 July 2004, 2, 677-690, (2004).

[6] Heinrichs, K., Diagnose der Verwitterungsschäden an den Felsmonumenten der antiken Stadt Petra/Jordanien.- Dissertation - RWTH Aachen, Aachener Geowissenschaftliche Beiträge, Band 41, Wissenschaftsverlag Mainz, Aachen, (2005).

[7] Price, D.G., Weathering and weathering process, Quarterly Journal of Engineering Geology, 28, 243-252, (1995).

[8] Dal, M., Öcal, A.D., Investigations on Stone weathering of Ottoman Architecture: A Kirklareli Hizirbey Kulliye case study, Paripex-Indian Journal of Research, 2, 11, (2013).

[9] Siegesmund, S., Auras, M., Snethlage, R. (eds.), Stein. Zerfall und Konservierung, Edition Leipzig, Leipzig, (2005).

[10] Öcal, A. D., Deterioration of Archaeological Environment in the Eastern Mediterranean, Homer Yayınevi, Istanbul, (2000).

[11] Küçükkaya, A. G., Taşların Bozulma Nedenleri ve Koruma Yöntemleri, Birsen Yayınevi, İstanbul, (2004).

[12] Dal, M., Irgas, C., Doğal taşlar üzerindeki biyolojik organizmaların alterasyondaki rolü, Trakya Universty Journal Engineering Science, 13, 1, 41-55, (2012).

[13] Dal, M., Umaroğulları, G., A petrografic and chemical analysis of the degree of deformation in historical building stones in Edirne, International Journal of Scientific Research, 3, 3, 392-395, (2014). 
[14] Dal, M., Öcal, A. D., Limestone used in Islamic religious architecture from Istanbul and Turkish Thrace, METU Journal of the Faculty of Architecture, 30, 1, 29-44, (2013).

[15] Dal, M., Dolomitics stones at historical buildings in Edirne, 2nd International Symposium on Architect Sinan-Spirit of the Place Edirne, 13-14 April 2006, Trakya University, Congress\&Cultural Center Edirne/TURKEY, 73-84, (2006).

[16] Dal, M., Clay minerals and their effects at stones of Edirne historic building, Trakya University Journal of Engineering Sciences, 13, 1, 31-39, (2012).

[17] Dal, M., Trakya bölgesi tarihi yapılarında kullanılan karbonatlı taşların bozunma nedenleri, T.C. Başbakanlık Vakıflar Genel Müdürlüğü Vakıflar Dergisi, 34, 2, 47-59, (2010). 